\title{
Cost Effective Adsorption of Aluminium and Iron from Synthetic and Real Wastewater by Rice Hull Activated Carbon (RHAC)
}

\author{
Nour T. Abdel-Ghani' ${ }^{1}$, Ghadir A. El-Chaghaby ${ }^{2}$, Enas Mohamed Zahran ${ }^{3}$ \\ ${ }^{1}$ Chemistry Department, Faculty of science, Cairo University, Cairo, Egypt \\ ${ }^{2}$ RCFF, Agricultural Research Center, Giza, Egypt \\ ${ }^{3}$ Holding Company for Water and Wastewater, Greater Cairo Water Company, Cairo, Egypt \\ Email: noureta2002@yahoo.com, ghadiraly@yahoo.com
}

Received 24 November 2014; accepted 6 January 2015; published 15 January 2015

Copyright (C) 2015 by authors and Scientific Research Publishing Inc.

This work is licensed under the Creative Commons Attribution International License (CC BY). http://creativecommons.org/licenses/by/4.0/

cc) (7)

Open Access

\begin{abstract}
The adsorption of aluminium(III) and iron(III) ions from their single and binary systems, by RHAC was investigated in a batch system. The activated carbon prepared from rice hulls was characterized by scanning electron microscopy and Fourier transformation infrared techniques. Batch adsorption experiments were performed under different operating conditions including $\mathrm{pH}(2-5)$, adsorbent dosage $(0.5-2.0 \mathrm{~g} / \mathrm{l})$, initial ion concentration $(5-100 \mathrm{mg} / \mathrm{l})$, and contact time $(30-240$ min). The equilibrium time for maximum ions removal was found to be $180 \mathrm{~min}$ in single and binary ions systems. The kinetics of adsorption was evaluated using the pseudo-first order, pseudosecond order and Elovich kinetic models. The Langmuir, Freundlich and Temkin equilibrium models were applied to the adsorption experimental data. Real wastewater samples were collected from different locations to investigate the efficiency of rice hull activated carbon in treating real samples. The real wastewater samples were treated with the activated carbon prepared from rice hulls and a commercial activated carbon. The results showed that the activated carbon prepared in the present work was more efficient in the removal of aluminium and iron from real wastewater as compared to the commercial activated carbon which is more advantageous considering both economics and environmental parameters.
\end{abstract}

\section{Keywords}

Aluminium, Iron, Adsorption, Rice Hulls, Activated Carbon, Kinetics, Equilibrium

\footnotetext{
"Corresponding author.
} 


\section{Introduction}

The presence of inorganic pollutants in water is a problematic environmental issue. The problem with metal ions pollution is that they are not biodegradable and are highly persistent in the environment [1]. Different sources contribute to the presence of metal ions in water. Iron is routinely detected in municipal waste effluent, particularly in cities where iron and steel are manufactured [2]. Aluminium is usually present in alum treated water, effluents from aluminum based industries and also due to the salts of aluminum added to many processed foods and medicine [3].

Different methods have been used for the removal of metal ions from contaminated water. The commonly used procedures for removing metal ions from aquatic ecosystems include chemical precipitation, reverse osmosis and solvent extraction [4]. These methods have disadvantages such as secondary pollution, high cost, high energy input, large quantities of chemical reagents or poor treatment efficiency at low metal concentration [5].

According to Ahmaruzzaman [6], in accordance with the very abundant literature data, liquid-phase adsorption is one of the most popular methods for the removal of toxic pollutants from wastewater, since proper design of the adsorption process will produce a high-quality treated effluent. Adsorption with activated carbon is one of the most efficient processes for water decontamination [7]. However, according to Loredo-Cancino et al. [8] despite of these advantages, the use of commercial activated carbon as an adsorbent is often limited for economic reasons, and many researchers have paid attention to the use of alternative precursors, such as agro-waste materials, for activated carbon production.

In Egypt, about 0.5 million tons of rice hulls are produced every year from the rice fields and rice milling process [9]. Thus in the present study, rice hulls are used as a precursor material for the preparation of activated carbon. According to Okutani [10], rice hulls are agricultural by-products with 13 to 29 wt\% inorganic components and 71 to 87 wt\% organic components such as cellulose depending on the species, climate and geographic location of growth. The inorganic components contain $87 \%$ to $97 \% \mathrm{SiO}_{2}$ in hydrated amorphous form with small amounts of alkali and other trace elements.

The aim of the present work is to prepare activated carbon from rice hulls (RHAC) and to characterize and investigate its adsorption efficiency towards the removal of iron and aluminium from their single and binary ion solutions in batch experiments considering all parameters affecting such processes as well as their kinetics and equilibrium.

\section{Materials and Methods}

\subsection{Preparation of Rice Hulls Activated Carbon (RHAC)}

Rice hulls used as a starting material for the preparation of activated carbon were obtained from the Egyptian Starch \& Glucose Manufacturing Company (ESGC).

The activated carbons from rice hulls (RHAC) were prepared according to the procedure described by [11] with some modification. Rice hulls were cleaned with water and dried at $110^{\circ} \mathrm{C}$ for $48 \mathrm{~h}$. The dried samples were crushed with a blender and sieved before they were carbonized at $400^{\circ} \mathrm{C}$ for $1 \mathrm{~h}$ in a muffle furnace in order to produce charcoal. The charcoals obtained were then subjected to impregnation in $\mathrm{NaOH}$ solution by weight ratio ( $1 \mathrm{~g}$ charcoal: $4 \mathrm{~g} \mathrm{NaOH})$ at $70^{\circ} \mathrm{C}$ for $24 \mathrm{~h}$. After that, it was dried in oven at $110^{\circ} \mathrm{C}$ for $24 \mathrm{~h}$. The resulted samples were further activated in a muffle furnace at $800^{\circ} \mathrm{C}$ for 2 hrs. After cooling, the activated carbons were washed successively several times with $1 \mathrm{M} \mathrm{HCl}$ followed by hot water until the pH became neutral (=7). Finally the washed samples were dried at $110^{\circ} \mathrm{C}$.

\subsection{Adsorbent Characterization}

The prepared activated carbons were characterized by Fourier transformation infrared technique (FTIR) over the range of $500-4000 \mathrm{~cm}^{-1}$ using Thermo Nicolet Avatar 370 FTIR Spectrometer, Thermo scientific co. The surface characteristics of the adsorbents were also investigated by scanning electron microscope (SEM) using JEOL, JSM-6490LA Scanning Electron Microscope-JEOL USA, Inc.

\subsection{Batch Adsorption Studies}

Batch experiments were conducted to study the factors affecting the adsorption of $\mathrm{Al}(\mathrm{III})$ and $\mathrm{Fe}(\mathrm{III})$ onto 
RHAC. At the beginning of each experimental run, a known weight of RHAC was added to $50 \mathrm{ml}$ solution containing a known concentration of single or binary aluminium(III) and iron(III) ions. The studied factors were $\mathrm{pH}$ (2 - 5), adsorbent dosage ( 0.5 - $2.0 \mathrm{~g} / \mathrm{l})$, initial ion concentration (5 - $100 \mathrm{mg} / \mathrm{l})$, and contact time (30 - $240 \mathrm{~min})$. The flasks were agitated in a shaking water bath at a $200 \mathrm{rpm}$ constant shaking rate until equilibrium was reached. The mixture was then filtered and the remaining aluminium and/or iron concentrations were determined at 396.153 and $259.939 \mathrm{~nm}$, respectively using atomic absorption spectrometer (Shimadzu, model AA-6300, Japan).

The amount of ions adsorbed at equilibrium (adsorption capacity), $\mathrm{q}_{\mathrm{e}}(\mathrm{mg} / \mathrm{g})$, was calculated by the following equation:

$$
\mathrm{q}_{\mathrm{e}}=\left[\frac{\mathrm{C}_{\mathrm{i}}-\mathrm{C}_{\mathrm{e}}}{\mathrm{w}}\right] * \mathrm{~V}
$$

whereas the ions removal percentage (R\%) was calculated by the following equation:

$$
\mathrm{R} \%=\left[\frac{\mathrm{C}_{\mathrm{i}}-\mathrm{C}_{\mathrm{e}}}{\mathrm{C}_{\mathrm{i}}}\right] * 100
$$

where $C_{i}$ and $C_{e}$ are the ions concentrations at the initial time and at equilibrium (mg/l), respectively. $V$ is the volume of the solution (l) and $\mathrm{W}$ is the mass of adsorbent used (g).

\subsection{Application of RHAC for Real Water Samples Treatment}

Seven water samples (S1, S2, S3, S4, S5, S6 and S7; three replicates each) were collected from different locations as given in Table 1. Water sampling was achieved by "grab sampling technique" according to the "EPA Guidelines for water and wastewater sampling” [12].

To compare the efficiency of RHAC and CAC for the removal of aluminium and iron from real wastewaters: $50 \mathrm{ml}$ of each water sample were mixed with $0.1 \mathrm{~g}$ of RHAC or commercial activated carbon (CAC) obtained from Norit co. The samples were shaken for 240 min then they were separated from the adsorbent by filtration and finally the remaining concentrations of metal ions were determined.

\section{Results and Discussion}

\subsection{Effect of Contact Time on Single and Binary Al(III) and Fe(III) Adsorption}

The removal of $\mathrm{Al}(\mathrm{III})$ and $\mathrm{Fe}(\mathrm{III})$ from their single ion solutions as a function of contact time at different initial ions concentration is represented in Figure 1. It can be seen that the adsorption of both ions was low at the start, then increased by increasing the contact time and attained its maximum value after $180 \mathrm{~min}$. of contact time with the studied adsorbent. The adsorption capacity of RHAC increased by increasing the initial ions concentration in the solution.

Figure 2 shows the removal percentages of $\mathrm{Al}(\mathrm{III})$ and $\mathrm{Fe}(\mathrm{III})$ in single and binary systems at various contact time and at an initial ions concentration of $25 \mathrm{mg} / \mathrm{l}$, adsorbent dose of $1 \mathrm{~g} / \mathrm{l}$ and initial $\mathrm{pH}=4$. The results

\begin{tabular}{|c|c|c|c|c|}
\hline Sample & Location & $\mathrm{pH}$ & Temperature & Metal concentration \\
\hline $\mathrm{S} 1$ & Fostat station & 7.45 & $20.8^{\circ} \mathrm{C}$ & $\mathrm{Al}(0.583 \mathrm{mg} / \mathrm{l})$ \\
\hline $\mathrm{S} 2$ & Sludge & 7.39 & $19.2^{\circ} \mathrm{C}$ & $\mathrm{Al}(0.456 \mathrm{mg} / \mathrm{l})$ \\
\hline S3 & Shoubra El-khima station & 7.62 & $21.8^{\circ} \mathrm{C}$ & $\mathrm{Al}(0.363 \mathrm{mg} / \mathrm{l})$ \\
\hline S4 & Iron and steel factory & 6.84 & $20.9^{\circ} \mathrm{C}$ & $\mathrm{Fe}(3.478 \mathrm{mg} / \mathrm{l})$ \\
\hline S5 & Iron and steel factory (cooling area) & 6.57 & $21.8^{\circ} \mathrm{C}$ & $\mathrm{Fe}(0.726 \mathrm{mg} / \mathrm{l})$ \\
\hline S6 & From Shoubra El-khima station & 7.95 & $19.8^{\circ} \mathrm{C}$ & $\mathrm{Fe}(0.477 \mathrm{mg} / \mathrm{l})$ \\
\hline S7 & Nile during the rains & 8.35 & $20.5^{\circ} \mathrm{C}$ & Fe (2.908 mg/l) \\
\hline
\end{tabular}

Table 1. Samples locations and characteristics. 


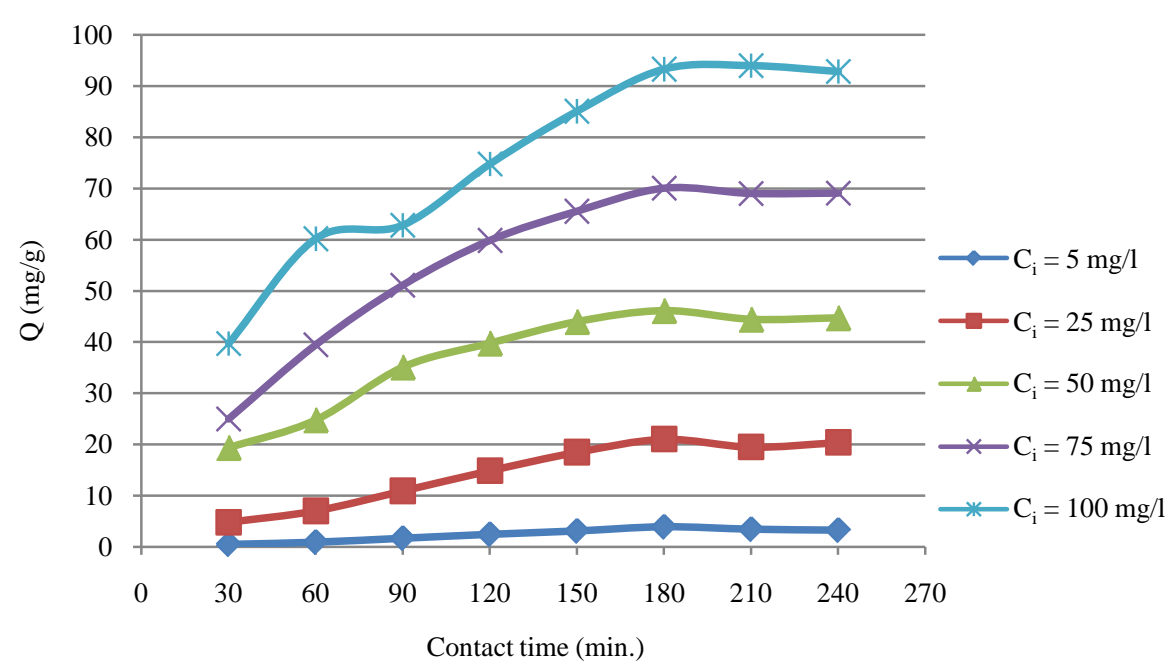

(a)

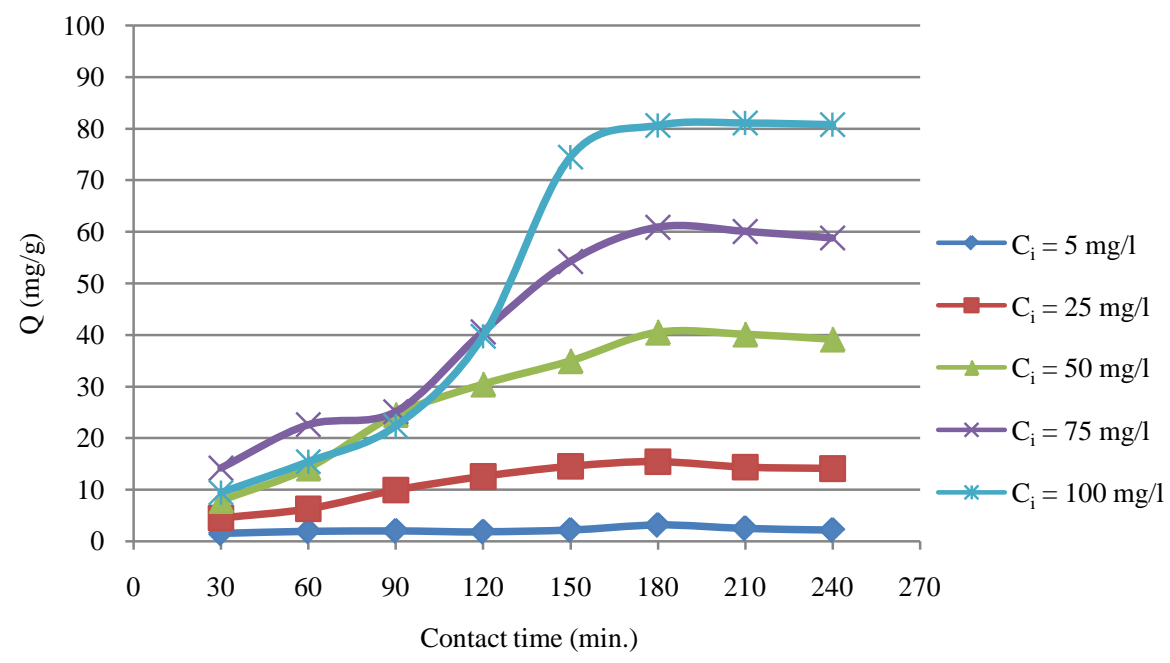

(b)

Figure 1. Adsorption of (a) $\mathrm{Al}(\mathrm{III})$ and (b) $\mathrm{Fe}(\mathrm{III})$ as function of contact time.

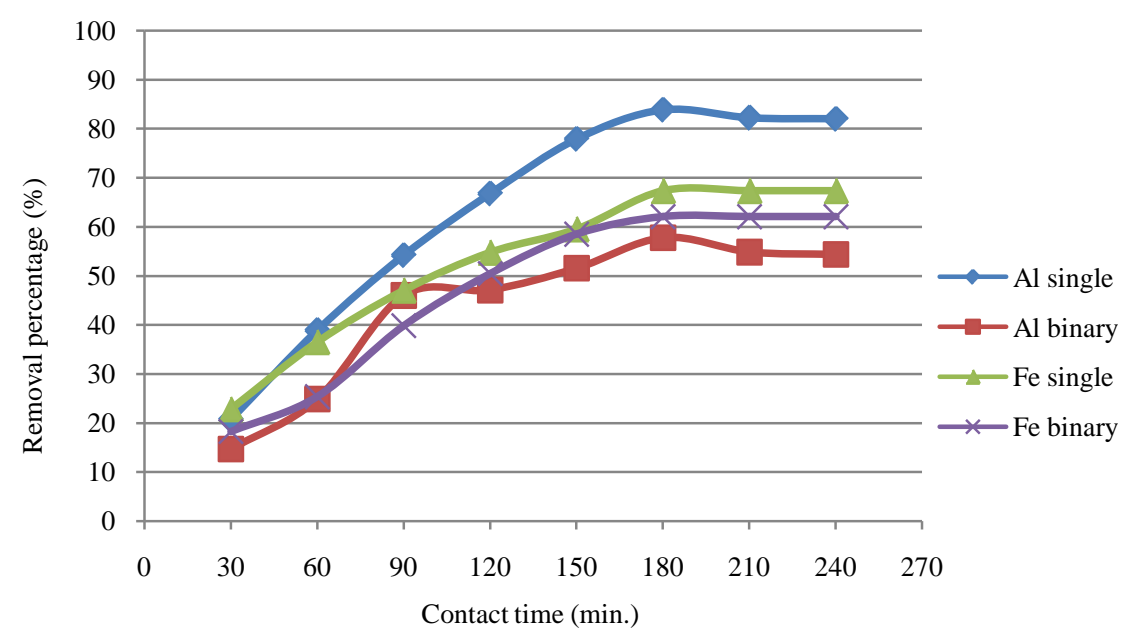

Figure 2. Removal percentages of $\mathrm{Al}(\mathrm{III})$ and $\mathrm{Fe}(\mathrm{III})$ in single and binary system at different contact time. 
showed that although the equilibrium time for maximum ions removal was the same in single and binary ions systems, but the removal percentages attained was higher in single than in binary ions systems. The maximum removal of $\mathrm{Al}(\mathrm{III})$ in its single ion solution was $82 \%$ and decreased to $54 \%$ in the binary aluminum-iron solution. Similarly, the maximum Fe(III) removal was $67 \%$ in the single iron solution and decreased to $62 \%$ in binary aluminum-iron solution system. Similar findings were obtained by Lugo-Lugo et al. [13] for the biosorption of chromium and iron from their single and binary systems. Also in agreement with these results Uslu and Tanyol [14] stated that the presence different components in the solution creates a competition for the adsorption sites on the surface and some sites are occupied by the second component. As a consequence, the first component has a smaller parking space and its uptake is decreased.

\subsection{Single and Binary Al(III) and Fe(III) Kinetics Analysis}

In order to analyze the adsorption kinetics of $\mathrm{Al}(\mathrm{III})$ and $\mathrm{Fe}(\mathrm{III})$ adsorption by RHAC in single and binary systems, pseudo-first order, pseudo-second order and Elovich kinetic models were applied to the experimental data.

The pseudo-first order model is represented by: $\ln \left(q_{e}-q_{t}\right)=\ln q_{e}-K_{1} t$ [15]. The pseudo-second-order equation [16] based on equilibrium adsorption is expressed as: $t / q=1 / \mathrm{K}_{2} \mathrm{q}_{\mathrm{e}}^{2}+\mathrm{t} / \mathrm{q}_{\mathrm{e}}$. Finally, according to El-Ashkouty [17] the simple Elovich's model is expressed as $q_{t}=\alpha+\beta \ln t$. Where $k_{1}\left(\min ^{-1}\right)$ is the pseudo first order adsorption rate coefficient, $\mathrm{k}_{2}(\mathrm{~g} / \mathrm{mg} \cdot \mathrm{min})$ is the rate constant of second-order adsorption, $\mathrm{q}_{\mathrm{e}}$ and $\mathrm{q}_{\mathrm{t}}$ are the values of amount adsorbed per unit mass at equilibrium and at any time (t), respectively. The parameter $\alpha$ is the initial sorption rate constant $(\mathrm{mg} / \mathrm{g} \cdot \mathrm{min})$ and $\beta$ is related to the extent of surface coverage and activation energy for chemisorptions ( $\mathrm{g} / \mathrm{mg})$.

The kinetic constants and the determination coefficients for the three tested models are summarized in Table 2. The results obtained were interpreted by considering the determination coefficient values obtained and also by comparing the values of the adsorption capacities calculated from the models ( $\mathrm{q}_{\mathrm{e}}$, calc.) with those obtained experimentally ( $\mathrm{q}_{\mathrm{e}}$, exp.).

The results indicated that in both single and binary systems, the adsorption of $\mathrm{Al}(\mathrm{III})$ and $\mathrm{Fe}(\mathrm{III})$ was found to be best described by the pseudo-second order model as well as the Elovich's model. On the other hand, the pseudo first order model showed the least fit to the data. The adequacy of the pseudo second order model to fit the adsorption data suggests that the rate-limiting step is a chemical sorption or chemisorptions involving valence forces through sharing or exchange of electrons between adsorbate and adsorbent [18]. Moreover, the applicability of both pseudo-second-order and Elovich kinetic models to the experimental data gives a further confirms that chemisorptions is the dominant process in controlling [19].

The results also showed that there was a noticeable reduction in RHAC adsorption capacity values towards both studied ions in the binary system as compared to the single systems which seems logic referring statistical vacant active adsorbent sites capacity of RHAC.

\subsection{Effect of $\mathrm{pH}$ on $\mathrm{Al}(\mathrm{III})$ and $\mathrm{Fe}(\mathrm{III})$ Adsorption onto RHAC}

Based on previously published studies, the effect of $\mathrm{pH}$ on the removal of aluminum and iron ions by RHAC

Table 2. Kinetic models constants for Al(III) and Fe(III) adsorption by RHAC in single and binary systems.

\begin{tabular}{|c|c|c|c|c|c|c|c|c|c|c|}
\hline & \multicolumn{3}{|c|}{ Pseudo-first order } & \multicolumn{3}{|c|}{ Pseudo-first order } & \multicolumn{3}{|c|}{ Elovich model } & \multirow[b]{2}{*}{$\mathrm{q}_{\mathrm{e}}(\mathrm{exp})}$. \\
\hline & $\begin{array}{c}\mathrm{k}_{1} \\
(\mathrm{~L} / \mathrm{min})\end{array}$ & $\begin{array}{l}\mathrm{q}_{\mathrm{e}, \text { calc. }} \\
\text { (mg/g) }\end{array}$ & $\mathrm{R}^{2}$ & $\begin{array}{c}\mathrm{k}_{2} \\
\text { (g/mg.min) }\end{array}$ & $\begin{array}{c}\mathrm{q}_{\mathrm{e}, \text { calc. }} \\
(\mathrm{mg} / \mathrm{g})\end{array}$ & $\mathrm{R}^{2}$ & $\begin{array}{c}\alpha \\
\text { (mg/g.min) }\end{array}$ & $\begin{array}{c}\beta \\
(\mathrm{g} / \mathrm{mg})\end{array}$ & $\mathrm{R}^{2}$ & \\
\hline \multicolumn{11}{|c|}{ Single ion system } \\
\hline $\mathrm{Al}(\mathrm{III})$ & 0.015 & 30.88 & 0.93 & $6.20 \times 10^{-3}$ & 21.74 & 0.96 & 9.17 & 26.82 & 0.95 & 22.07 \\
\hline $\mathrm{Fe}(\mathrm{III})$ & 0.017 & 27.94 & 0.90 & $8.13 \times 10^{-4}$ & 22.73 & 0.99 & 7.74 & 20.52 & 0.96 & 20.61 \\
\hline \multicolumn{11}{|c|}{ Binary ions system } \\
\hline $\mathrm{Al}(\mathrm{III})$ & 0.016 & 19.12 & 0.98 & $1.17 \times 10^{-3}$ & 19.60 & 0.99 & 6.02 & 17.50 & 0.98 & 14.20 \\
\hline $\mathrm{Fe}(\mathrm{III})$ & 0.012 & 15.20 & 0.95 & $1.36 \times 10^{-3}$ & 18.87 & 0.99 & 5.78 & 14.11 & 0.98 & 16.86 \\
\hline
\end{tabular}


was studied in the range between $\mathrm{pH} 2$ and 5 to avoid metal ions hydroxide precipitation at higher $\mathrm{pH}$ values [20] and [21]. Figure 3 represents the removal percentage of aluminium and iron ions at different initial $\mathrm{pH}$ values.

It is clear that the removal of both metal ions was low at $\mathrm{pH} 2$ and increased by increasing the $\mathrm{pH}$ value of the metal ions solution. It is generally agreed that at very low $\mathrm{pH}$ values the metal ions removal is weak due to the competition between the positively charged hydronium ions present in solution and the metal ions to occupy the adsorbent's active sites. As the solution $\mathrm{pH}$ is raised less hydronium ions are present and thus the opportunity of the positively charged metal ions to occupy the adsorbent's surface increases. The maximum removal of aluminum and iron ions due to adsorption was obtained at $\mathrm{pH} 5$ and $\mathrm{pH} 3$, respectively (Figure 3). Thus a middle $\mathrm{pH}$ value $(\mathrm{pH}=4)$ was used in all subsequent experiments.

In agreement with our results; Cayllahua and Torem [22] stated that at $\mathrm{pH} 5$ the optimum removal of aluminum ions onto Rhodococcus opacus was obtained. The $\mathrm{pH} 4.5$ was selected as the optimum $\mathrm{pH}$ for aluminum ions removal by P. pavonica biomass [23]. Similarly, Kousalya et al. [24] reported pH 3 to be the optimum $\mathrm{pH}$ for $\mathrm{Fe}(\mathrm{III})$ by nano-biocomposites. Also Quintelas et al. [25] reported $\mathrm{pH} 3.5$ as the optimum $\mathrm{pH}$ for ferric ions removal onto E. coli biofilm supported on kaolin.

\subsection{Single and Binary Al(III) and Fe(III) Equilibrium Modeling}

The adsorption of $\mathrm{Al}(\mathrm{III})$ and Fe(III) by RHAC was analyzed by well documented Langmuir (Equation (4)) [26], Freundlich (Equation (5)) [27], Temkin (Equation (6)) [28] and Dubinin-Radushkevich (Equation (7)) [29] isotherm models.

$$
\begin{gathered}
\mathrm{C}_{\mathrm{eq}} / \mathrm{q}_{\mathrm{e}}=1 / \mathrm{bq}_{\max }+\mathrm{C}_{\mathrm{eq}} / \mathrm{q}_{\max } \\
\log \mathrm{q}_{\mathrm{e}}=\log \mathrm{k}_{\mathrm{f}}+(1 / \mathrm{n}) \log \mathrm{C}_{\mathrm{eq}} \\
\mathrm{q}_{\mathrm{eq}}=\mathrm{a}_{\mathrm{t}}+\mathrm{b}_{\mathrm{t}} \ln \mathrm{C}_{\mathrm{eq}} \\
\ln \mathrm{q}_{\mathrm{e}}=\ln \mathrm{q}_{\mathrm{m}}-\beta \varepsilon^{2}
\end{gathered}
$$

where: $\mathrm{C}_{\text {eq }}$ : equilibrium concentration in $\mathrm{mg} / \mathrm{l}$; $\mathrm{q}_{\mathrm{e}}$ : equilibrium capacity in $\mathrm{mg} / \mathrm{g}$; $\mathrm{q}_{\max }$ : maximum capacity in $\mathrm{mg} / \mathrm{g} ; \mathrm{b}(\mathrm{l} / \mathrm{mg})$ is Langmuir constant; $\mathrm{k}_{\mathrm{f}}$ and $\mathrm{n}$ are Freundlich constants; $\mathrm{b}_{\mathrm{t}}$ and $\mathrm{a}_{\mathrm{t}}$ are Temkin isotherm constants; $\mathrm{q}_{\mathrm{m}}$ is the theoretical saturation capacity $(\mathrm{mg} / \mathrm{g}), \beta$ is a constant related to the mean free energy of adsorption per mole of the adsorbate $\left(\mathrm{mg}^{2} / \mathrm{J}^{2}\right)$, and $\varepsilon$ is the Polanyi potential.

The adsorption free energy ( $\mathrm{E} ; \mathrm{kJ} / \mathrm{mol}$ ) can be calculated from the $\mathrm{D}-\mathrm{R}$ model as follows: $\mathrm{E}=1 / \sqrt{ }-2 \beta$.

All the parameters calculated from the studied equilibrium models along with the correlation coefficients $\left(\mathrm{R}^{2}\right)$ are given in Table 3.

The coefficients of determination $\left(\mathrm{R}^{2}\right)$ for the Langmuir plots (Figure 4) were found to be $\geq 0.98$ for both aluminium and iron ions in their single and binary solutions. It can be concluded that the adsorption of the studied metal ions onto RHAC is well fitted to the Langmuir model. These results suggest that the adsorption of

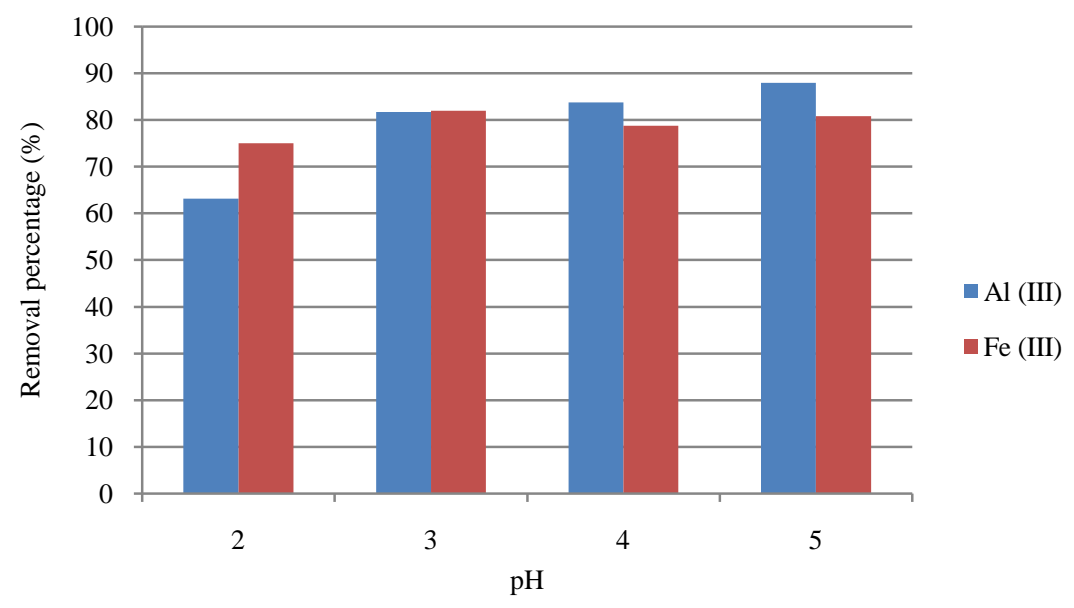

Figure 3. Effect of solution $\mathrm{pH}$ on the removal of $\mathrm{Al}(\mathrm{III})$ and $\mathrm{Fe}(\mathrm{III})$ by RHAC. 
Table 3. Equilibrium models constants for $\mathrm{Al}(\mathrm{III})$ and Fe(III) adsorption by RHAC in single and binary systems.

\begin{tabular}{|c|c|c|c|c|c|c|c|c|c|c|c|c|c|}
\hline & \multicolumn{3}{|c|}{ Langmuir model } & \multicolumn{3}{|c|}{ Freundlich model } & \multicolumn{3}{|c|}{ Temkin model } & \multicolumn{4}{|c|}{ Dubinin-Radushkevich (D-R) } \\
\hline & $\begin{array}{c}\mathrm{q}_{\max } \\
(\mathrm{mg} / \mathrm{g})\end{array}$ & $\begin{array}{c}\mathrm{b} \\
(\mathrm{l} / \mathrm{mg})\end{array}$ & $\mathrm{R}^{2}$ & $\mathrm{k}_{\mathrm{f}}$ & $\mathrm{n}$ & $\mathrm{R}^{2}$ & $a_{t}$ & $\mathrm{~b}_{\mathrm{t}}$ & $\mathrm{R}^{2}$ & $\begin{array}{c}\mathrm{q}_{\mathrm{m}} \\
(\mathrm{mg} / \mathrm{g})\end{array}$ & $\begin{array}{c}\beta \\
\left(\mathrm{mg}^{2} / \mathrm{J}^{2}\right)\end{array}$ & $\begin{array}{c}E \\
(\mathrm{KJ} / \mathrm{mol})\end{array}$ & $\mathrm{R}^{2}$ \\
\hline \multicolumn{14}{|c|}{ Single ion system } \\
\hline $\mathrm{Al}(\mathrm{III})$ & 34.48 & 0.05 & 0.98 & 1.16 & 0.47 & 0.97 & 51.85 & 32.05 & 0.78 & 91.83 & $2 \times 10^{-6}$ & 13.50 & 0.98 \\
\hline $\mathrm{Fe}(\mathrm{III})$ & 45.45 & 0.03 & 0.99 & 1.07 & 0.68 & 0.97 & 32.27 & 28.36 & 0.79 & 126.09 & $2 \times 10^{-5}$ & 8.85 & 0.98 \\
\hline \multicolumn{14}{|c|}{ Binary ions system } \\
\hline $\mathrm{Al}(\mathrm{III})$ & 21.28 & 0.08 & 0.99 & 1.65 & 0.54 & 0.96 & 39.63 & 37.77 & 0.71 & 73.33 & $4 \times 10^{-6}$ & 9.54 & 0.97 \\
\hline $\mathrm{Fe}(\mathrm{III})$ & 26.32 & 0.02 & 0.98 & 2.92 & 0.62 & 0.96 & 28.92 & 37.76 & 0.77 & 117.21 & $2 \times 10^{-5}$ & 8.2 & 0.97 \\
\hline
\end{tabular}

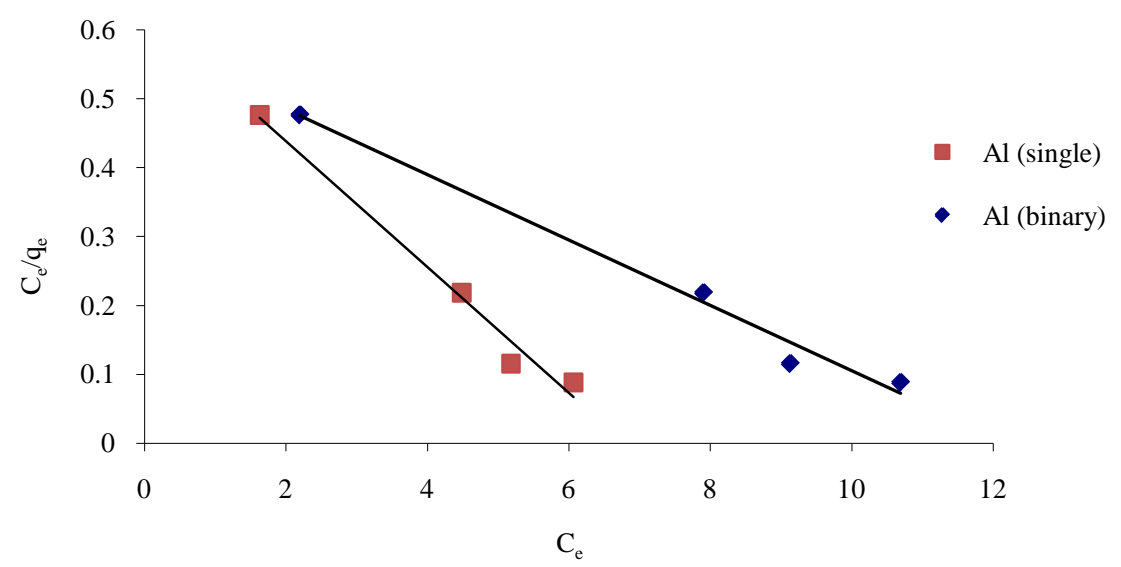

(a)

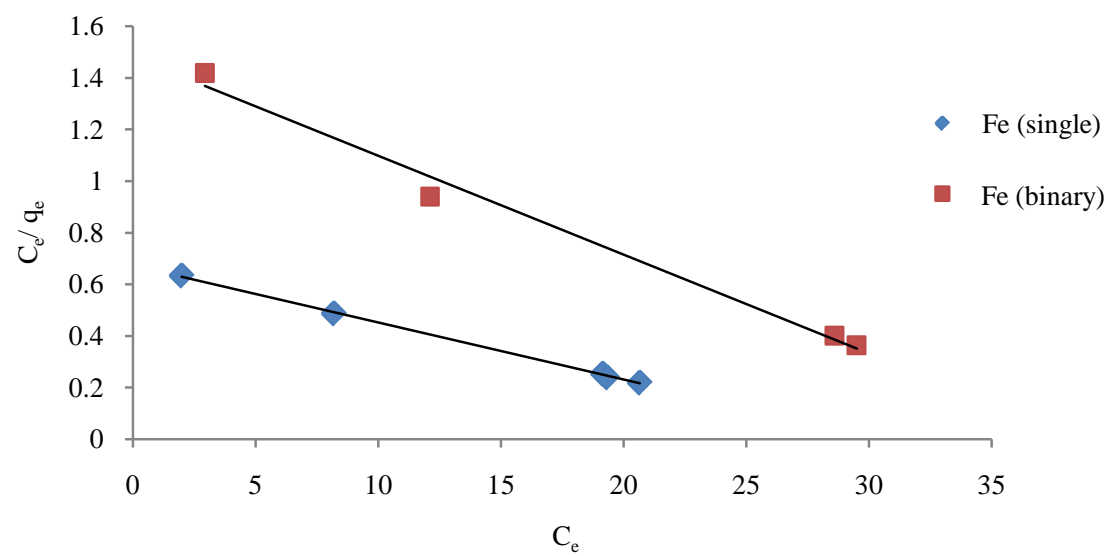

(b)

Figure 4. Langmuir plots for (a) Al(III) and (b) Fe (IIII) adsorption onto RHAC.

$\mathrm{Al}(\mathrm{III})$ and $\mathrm{Fe}(\mathrm{III})$ onto RHAC is a monolayer adsorption taking place at the surface groups binding sites of the adsorbent. The maximum adsorption capacities calculated from the Langmuir model were found to be 34.48 and $45.45 \mathrm{mg} / \mathrm{g}$ for aluminium and iron in their single solutions and 21.28 and $26.32 \mathrm{mg} / \mathrm{g}$ for aluminium and iron in their binary solutions, respectively. It is clear that the maximum capacity of the metal ions in their single solutions was higher than the maximum capacity values recorded in the binary ions solution. A comparison between the maximum Langmuir capacity values obtained in the present study with those previously reported in literature 
for aluminium and iron adsorption onto various adsorbents is given in Table 4.

The Freudlich model plots obtained for the experimental data are given in Figure 5. The $\mathrm{R}^{2}$ values of the Freundlich model ( 0.97 and 0.96 for both aluminium and iron ions in their single binary solutions, respectively) were found to be lower than those obtained for the Langmuir model. These results suggest that the adsorption of $\mathrm{Al}(\mathrm{III})$ and $\mathrm{Fe}$ (III) onto RHAC is not well described by the Freundlich model compared to the Langmuir model.

The plots of Dubinin-Radushkevich (D-R) isotherm are shown in Figure 6. The D-R model showed high determination coefficient values $\left(\mathrm{R}^{2} \geq 0.97\right)$ suggesting a good fit to the experimental data. The adsorption free energy (E; $\mathrm{kJ} / \mathrm{mol}$ ) can be calculated from the D-R model as follows: $\mathrm{E}=1 / \sqrt{ }-2 \beta$. The $\mathrm{E}(\mathrm{kJ} / \mathrm{mol})$ value gives information about the physical or chemical nature of the adsorption mechanism. If it lies between 8 and 16 $\mathrm{kJ} / \mathrm{mol}$, the adsorption process takes place chemically and while $\mathrm{E}<8 \mathrm{~kJ} / \mathrm{mol}$, the adsorption process proceeds physically [30]. As seen from Table 3, the values of $E$ for both aluminium and iron ions were found to be in the range 8 - $13 \mathrm{~kJ} / \mathrm{mol}$. Thus, the calculated values of $\mathrm{E}$ suggest that the adsorption process is chemisorptions.

On the other hands the Temkin isotherm model (Figure 7) did not show any fitness to the experimental data of $\mathrm{Al}(\mathrm{III})$ and $\mathrm{Fe}(\mathrm{III})$ adsorption onto RHAC with $\mathrm{R}^{2}$ values $<0.80$.

Based on the $\mathrm{R}^{2}$ values which is a measure of the goodness of model's fit [37], it can be concluded that the adsorption data of aluminium and iron ions fitted well to the Langmuir model followed by the D-R model.

The results also show that the maximum capacity of the metal ions in their single solutions was higher than the maximum capacity values recorded in the binary ions solution.

Table 4. Maximum Langmuir adsorption capacity of RHAC for Al(III) and Fe(III).

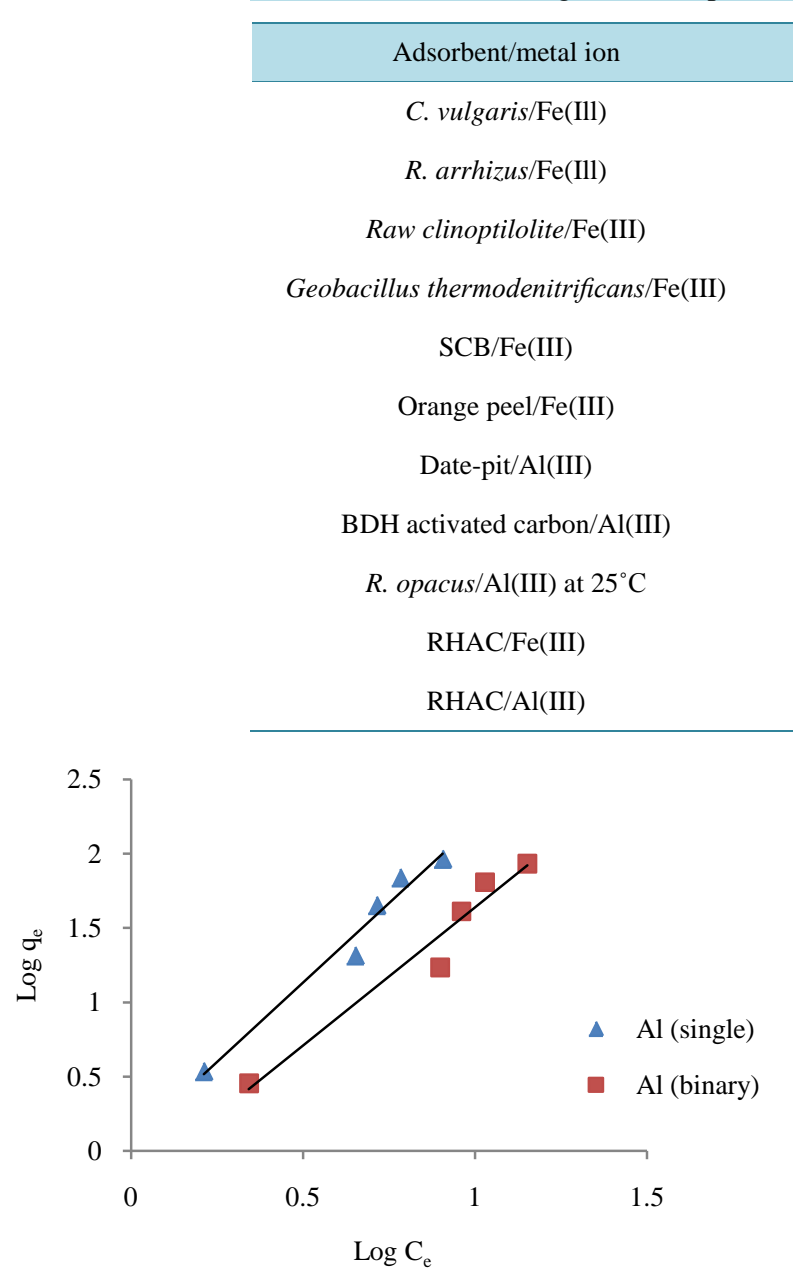

(a)

\begin{tabular}{cc}
$\mathrm{Q}_{\max }(\mathrm{mg} / \mathrm{g})$ & Reference \\
24.491 & {$[30]$} \\
34.733 & {$[30]$} \\
98.00 & {$[31]$} \\
79.9 & {$[32]$} \\
331.1 & {$[33]$} \\
9.4308 & {$[34]$} \\
5.831 & {$[35]$} \\
6.562 & {$[35]$} \\
41.584 & {$[36]$} \\
45.45 & Present study \\
34.48 & Present study \\
\hline
\end{tabular}

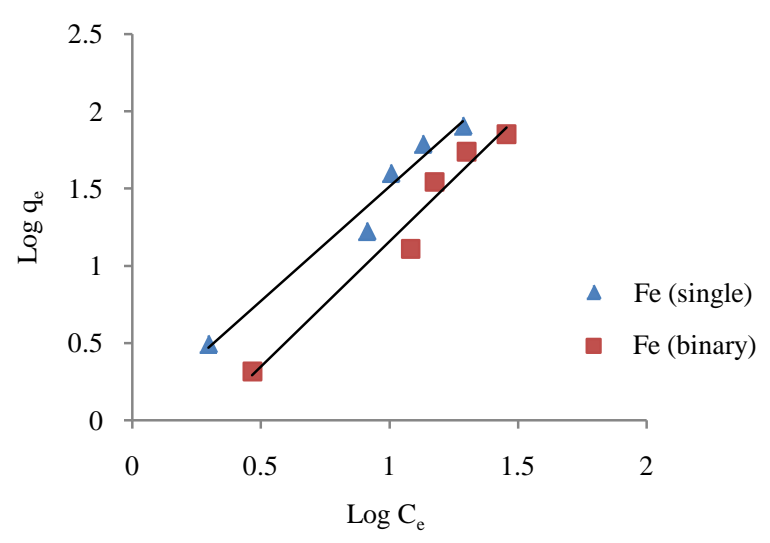

(b)

Figure 5. Freundlich plots for (a) $\mathrm{Al}(\mathrm{III})$ and (b) Fe(III) adsorption by RHAC. 


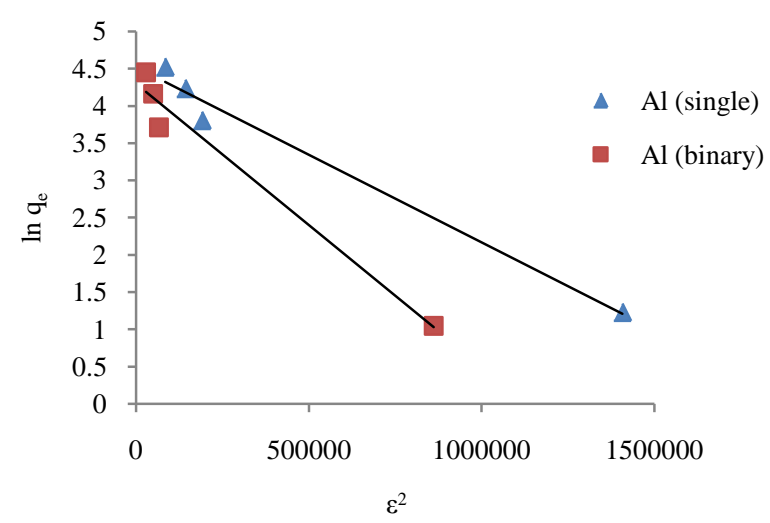

(a)

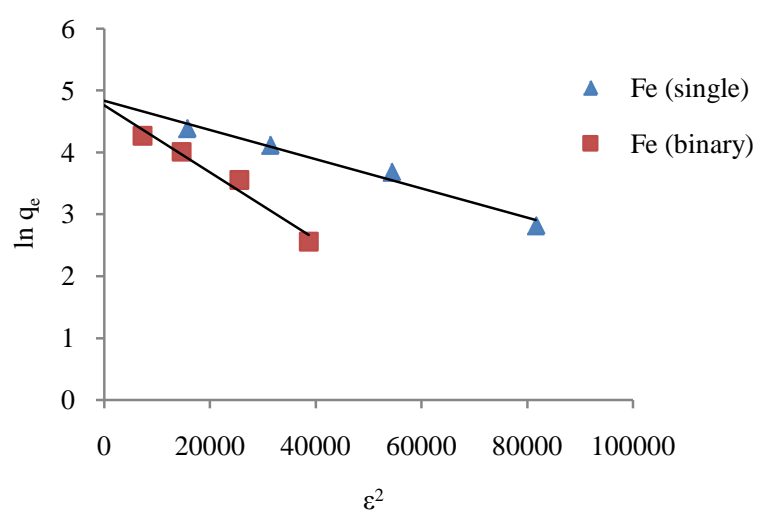

(b)

Figure 6. D-R plots for (a) $\mathrm{Al}(\mathrm{III})$ and (b) Fe(III) adsorption by RHAC.

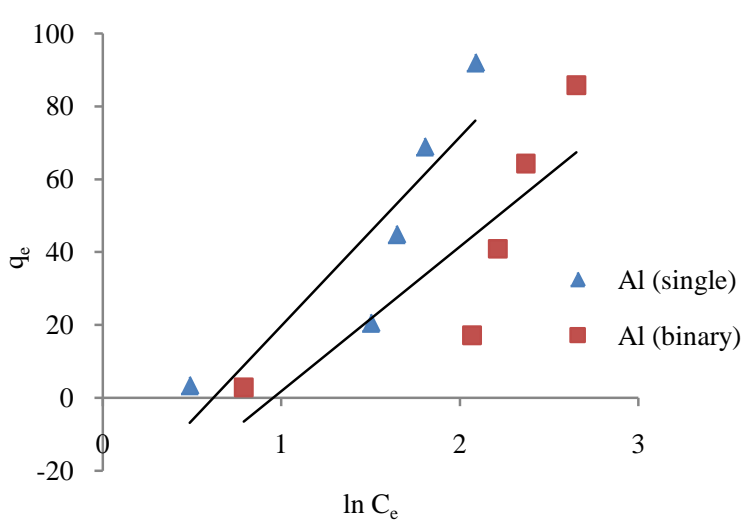

(a)

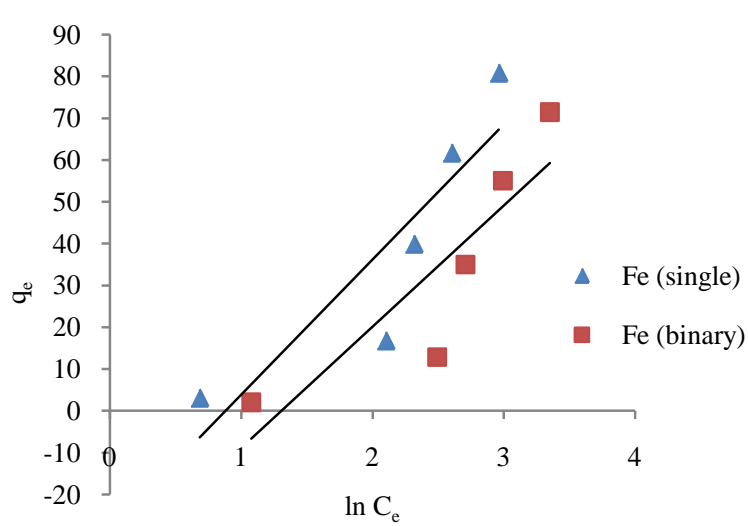

(b)

Figure 7. Temkin plots for (a) $\mathrm{Al}(\mathrm{III})$ and (b) Fe(III) adsorption by RHAC.

\subsection{Characterization of RHAC}

The activated carbon prepared from rice hull was characterized by FTIR and SEM techniques in order to identify the surface functional groups and surface morphology of the adsorbent.

The FT-IR spectrum of (RHAC) is shown in Figure 8. It can be observed that the spectrum displays a number of bands corresponding to several functional groups on the activated carbon surface that may facilitate the adsorption process. The spectrum of RHAC showed that a broad band at $3423 \mathrm{~cm}^{-1}$ this band is characteristic of the $\mathrm{OH}$ stretching vibrations mode of hydroxyl functional groups including hydrogen bonding of chemisorbed water or may be due to binding of $\mathrm{OH}$ group with polymeric structure of rice hulls [38]. The band at $2922 \mathrm{~cm}^{-1}$ could be attributed to C-H stretching of aliphatic carbon or it can be due to $\mathrm{CH}_{2}$ or $\mathrm{CH}_{3}$ deformation [38]. The peak at $1625 \mathrm{~cm}^{-1}$ related to $\mathrm{C}=\mathrm{C}$ stretching for unsaturated aliphatic structures [39]. The bands at 1099 and 798 could be due to Si-O-Si stretching and Si-H groups, respectively [40].

The scanning electron microscopy micrograph of RHAC is shown in Figure 9. The figure shows a variety of cavities as well as a porous morphology with pores of different shapes and sizes. This irregular surface format leads to increasing the contact area, which facilitates the pore diffusion during adsorption [41].

Thus by considering the FTIR surface bands and the surface morphological characteristics of RHAC, it can be inferred that RHAC possess a surface capable of adsorbing metal ions.

\subsection{Comparison of the Adsorption Efficiency of RHAC and Commercial Activated Carbon (CAC) for Real Wastewaters Treatment}

The results of real water samples treatment using RHAC and CAC are presented in Table 5. It can be observed that in all cases (RHAC) showed higher removal efficiency for aluminium and iron ions as compared to the 


\section{N. T. Abdel-Ghani et al.}

Table 5. Comparison of the removal percentages of aluminium and iron using RHAC and CAC.

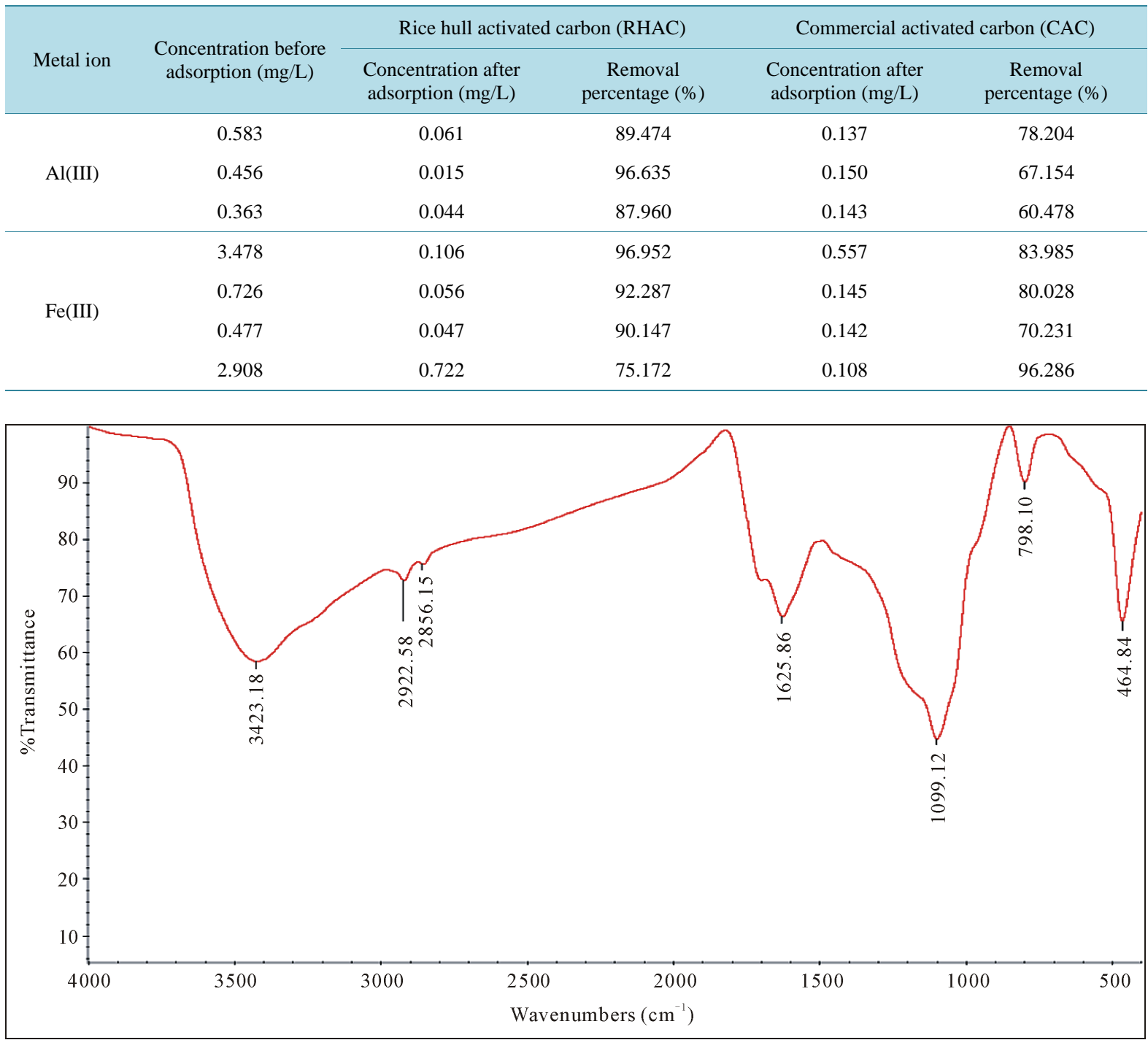

Figure 8. FTIR spectra of RHAC.

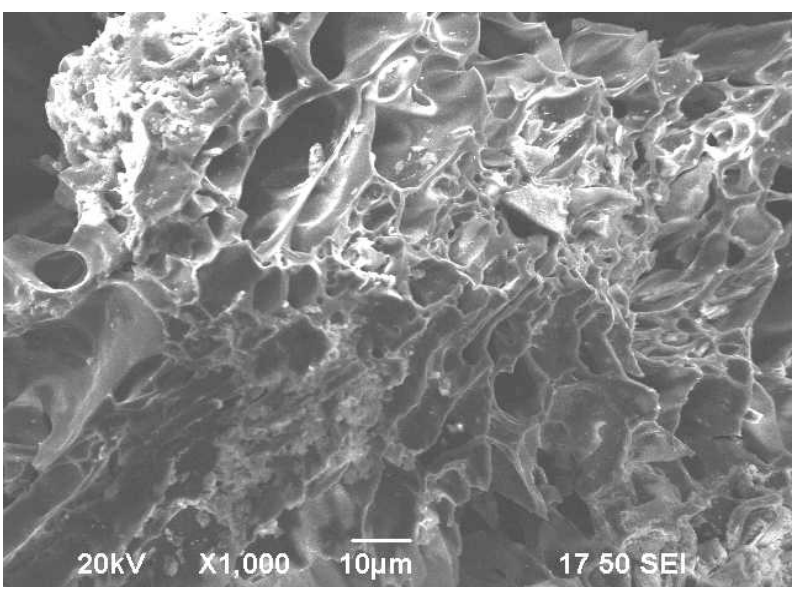

Figure 9. SEM micrograph of RHAC $(\times 1000)$. 
commercial activated carbon. It is worth to note that from an economic point of view, the use of RHAC will be more advantageous than the commercial activated carbon as RHAC is cost effective natural adsorbent.

\section{Conclusion}

In the present study, rice hulls were successfully used as a starting material for the preparation of a cost effective activated carbon. The prepared activated carbon showed good adsorption capacity for removing both aluminium and iron ions from their single and mixed ion solutions. The adsorption equilibrium was reached in 180 minutes. The adsorption of aluminium and iron was found to be well fitted to the pseudo-second order kinetic model and the Langmuir equilibrium model. The activated carbon prepared from rice hulls showed high aluminium and iron removal efficiency from real wastewater samples. It can be concluded that rice hulls could be effectively used for the production of cost effective activated carbons that could be applied for the removal of metal ions from wastewater.

\section{References}

[1] Wan Ngah, W.S. and Hanafiah, M.K.M. (2008) Removal of Heavy Metal Ions from Wastewater by Chemically Modified Plant Wastes as Adsorbents: A Review. Bioresource Technology, 99, 3935-3948. http://dx.doi.org/10.1016/j.biortech.2007.06.011

[2] Cho, B.-Y. (2005) Iron Removal Using an Aerated Granular Filter. Process Biochemistry, 40, 3314-3320. http://dx.doi.org/10.1016/j.procbio.2005.03.031

[3] Kumari, A.A. and Ravindhranath, K. (2012) Removal of Aluminium(III) from Polluted Waters Using Biosorbents Derived from Achiranthus Aspera and Cassia Occidentalis. International Journal of Water Resources and Arid Environments, 2, 8-19.

[4] Abdel-Ghani, N.T., Hegazy, A.K. and El-Chaghaby, G.A. (2009) Typha domingensis Leaf Powder for Decontamination of Aluminium, Iron, Zinc and Lead: Biosorption Kinetics and Equilibrium Modeling. International Journal of Environmental Science \& Technology, 6, 243-248. http://dx.doi.org/10.1007/BF03327628

[5] Ding, Y., Jing, D., Gong, H., Zhou, L. and Yang, X. (2012) Biosorption of Aquatic Cadmium(II) by Unmodified Rice Straw. Bioresource Technology, 114, 20-25. http://dx.doi.org/10.1016/j.biortech.2012.01.110

[6] Ahmaruzzaman, M. (2011) Industrial Wastes as Low-Cost Potential Adsorbents for the Treatment of Wastewater Laden with Heavy Metals. Advances in Colloid and Interface Science, 166, 36-59.

[7] Estevinho, B.N., Ratola, N., Alves, A. and Santos, L. (2006) Pentachlorophenol Removal from Aqueous Matrices by Sorption with Almond Shell Residues. Journal of Hazardous Materials, 137, 1175-1181. http://dx.doi.org/10.1016/j.jhazmat.2006.04.001

[8] Loredo-Cancino, M., et al. (2013) Determining Optimal Conditions to Produce Activated Carbon from Barley Husks Using Single or Dual Optimization. Journal of Environmental Management, 125, 117-125. http://dx.doi.org/10.1016/j.jenvman.2013.03.028

[9] Nour, A.M. (1987) Utilization of Agriculture By-Products as Livestock Feed in Africa. In: Plant Breeding and the Nutritive Value of Crop Residues, Proceedings of Workshop Held at Ryall's Hotel, Blantyre, Malawi September 1986. http://www.fao.org/wairdocs/ilri/x5494e/x5494e07.htm

[10] Okutani, T. (2009) Utilization of Silica in Rice Hulls as Raw Materials for Silicon Semiconductors. Journal of Metals, Materials and Minerals, 19, 51-59.

[11] Tongpoothorn, W., Sriuttha, M., Homchan, P., Chanthai, S. and Ruangviriyachai, C. (2011) Preparation of Activated Carbon Derived from Jatropha curcas Fruit Shell by Simple Thermo-Chemical Activation and Characterization of Their Physico-Chemical Properties. Chemical Engineering Research and Design, 89, 335-340. http://dx.doi.org/10.1016/j.cherd.2010.06.012

[12] Duncan, D., Harvey, F. and Walker, M. (2007) EPA Guidelines: Regulatory Monitoring and Testing Water and Wastewater Sampling. http://www.epa.sa.gov.au/xstd_files/Water/Guideline/guide_wws.pdf

[13] Lugo-Lugo, V., Barrera-Díaz, C., Ureña-Núñez, F., Bilyeu, B. and Linares-Hernández, I. (2012) Biosorption of Cr(III) and Fe(III) in Single and Binary Systems onto Pretreated Orange Peel. Journal of Environmental Management, 112, 120-127. http://dx.doi.org/10.1016/j.jenvman.2012.07.009

[14] Uslu, G. and Tanyol, M. (2005) Equilibrium and Thermodynamic Parameters of Single and Binary Mixture Biosorption of Lead (II) and Copper (II) Ions onto Pseudomonas putida: Effect of Temperature. Journal of Hazardous Materials, 135, 87-93. http://dx.doi.org/10.1016/j.jhazmat.2005.11.029

[15] Lagergren, S.Y. (1898) Zur Theorie der sogenannten Adsorption gelöster Stoffe. 
http://books.google.com.eg/books/about/Zur_Theorie_der_sogenannten_Adsorption_g.html

[16] Ho, Y.S. and McKay, G.A. (1998) Comparison of Chemisorption Kinetic Models Applied to Pollutant Removal on Various Sorbents. Process Safety and Environmental Protection, 76, 332-340. http://dx.doi.org/10.1205/095758298529696

[17] El-Ashtoukhy, E.-S.Z., Amin, N.K. and Abdelwahab, O. (2008) Removal of Lead (II) and Copper (II) from Aqueous Solution Using Pomegranate Peel as a New Adsorbent. Desalination, 223, 162-173. http://dx.doi.org/10.1016/j.desal.2007.01.206

[18] Xiong, Y., Xu, J., Snan, W., Lou, Z., Fang, D., Zang, S., et al. (2013) A New Approach for Rhenium(VII) Recovery by Using Modified Brown Algae Laminaria japonica Adsorbent. Bioresource Technology, 127, 464-472. http://dx.doi.org/10.1016/j.biortech.2012.09.099

[19] Kausar, A., Nawaz, H. and Mackinnon, G. (2013) Equilibrium, Kinetic and Thermodynamic Studies on the Removal of U (VI) by Low Cost Agricultural Waste. Colloids and Surfaces B: Biointerfaces, 111, 124-133. http://dx.doi.org/10.1016/j.colsurfb.2013.05.028

[20] Tassist, A., Lounici, H., Abdi, N. and Mameri, N. (2010) Equilibrium, Kinetic and Thermodynamic Studies on Aluminum Biosorption by a Mycelial Biomass (Streptomyces rimosus). Journal of Hazardous Materials, 183, 35-43. http://dx.doi.org/10.1016/j.jhazmat.2010.06.078

[21] Karabakan, A. (2008) Removal of Fe(III) Ion from Aqueous Solution by Adsorption on Raw and Treated Clinoptilolite Samples. Microporous and Mesoporous Materials, 111, 200-205.

[22] Cayllahua, J.E.B. and Torem, M.L. (2010) Biosorption of Aluminum ions onto Rhodococcus opacus from Wastewaters. Chemical Engineering Journal, 161, 1-8. http://dx.doi.org/10.1016/j.cej.2010.03.025

[23] Sari, A. and Tuzen, M. (2009) Equilibrium, Thermodynamic and Kinetic Studies on Aluminum Biosorption from Aqueous Solution by Brown Algae (Padina pavonica) Biomass. Journal of Hazardous Materials, 171, 973-979. http://dx.doi.org/10.1016/j.jhazmat.2009.06.101

[24] Kousalya, G.N., Rajiv Gandhi, M., Sairam Sundaram, C. and Meenakshi, S. (2010) Synthesis of Nano-Hydroxyapatite Chitin/Chitosan Hybrid Biocomposites for the Removal of Fe(III). Carbohydrate Polymers, 82, 594-599. http://dx.doi.org/10.1016/j.carbpol.2010.05.013

[25] Quintelas, C., Rocha, Z., Silva, B., Fonseca, B., Figueiredo, H. and Tavares, T. (2009) Removal of Cd(II), Cr(VI), $\mathrm{Fe}(\mathrm{III})$ and $\mathrm{Ni}(\mathrm{II})$ from Aqueous Solutions by an E. coli Biofilm Supported on Kaolin. Chemical Engineering Journal, 149, 319-324. http://dx.doi.org/10.1016/j.cej.2008.11.025

[26] Langmuir, I. (1916) The Constitution and Fundamental Properties of Solids and Liquids. Journal of the American Chemical Society, 38, 2221-2295. http://dx.doi.org/10.1021/ja02268a002

[27] Freundlich, H. (1906) Uber Die Adsorption in Losungen. Zeitschrift für Physikalische Chemie, 57, 385-470.

[28] Tempkin, M.J. and Pyzhev, V. (1940) Kinetics of Ammonia Synthesis on Promoted Iron Catalysts. Acta Physicochimica URSS, 12, 217-222.

[29] Dubinin, M.M. and Radushkevich, L.V. (1947) Equation of the Characteristic Curve of Activated Charcoal Proceedings of the Academy of Sciences. Physical Chemistry Section USSR, 55, 331-333.

[30] Sağ, Y., Açikel, Ü., Aksu, Z. and Kutsal, T. (1998) A Comparative Study for the Simultaneous Biosorption of Cr(VI) and $\mathrm{Fe}(\mathrm{III})$ on C. Vulgaris and R. arrhizus: Application of the Competitive Adsorption Models. Process Biochemistry, 33, 273-281. http://dx.doi.org/10.1016/S0032-9592(97)00060-5

[31] Öztaş, N.A., Karabakan, A. and Topal, Ö. (2008) Removal of Fe(III) Ion from Aqueous Solution by Adsorption on Raw and Treated Clinoptilolite Samples. Microporous and Mesoporous Materials, 111, 200-205. http://dx.doi.org/10.1016/j.micromeso.2007.07.030

[32] Soliman, E.M., Ahmed, S.A. and Fadl, A.A. (2011) Reactivity of Sugar Cane Bagasse as a Natural Solid Phase Extractor for Selective Removal of Fe(III) and Heavy-Metal Ions from Natural Water Samples. Arabian Journal of Chemistry, 4, 63-70. http://dx.doi.org/10.1016/j.arabjc.2010.06.021

[33] Chatterjee, S.K., Bhattacharjee, I. and Chandra, G. (2010) Biosorption of Heavy Metals from Industrial Waste Water by Geobacillus thermodenitrificans. Journal of Hazardous Materials, 175, 117-125. http://dx.doi.org/10.1016/j.jhazmat.2009.09.136

[34] Lugo-Lugo, V., Barrera-Díazb, C., Ureña-Núñezc, F., Bilyeud, B. and Linares-Hernándeze, I. (2012) Biosorption of $\mathrm{Cr}(\mathrm{III})$ and Fe(III) in Single and Binary Systems onto Pretreated Orange Peel. Journal of Environmental Management, 112, 120-127. http://dx.doi.org/10.1016/j.jenvman.2012.07.009

[35] Al-Muhtaseb, S.A., El-Naas, M.H. and Abdallah, S. (2008) Removal of Aluminum from Aqueous Solutions by Adsorption on Date-Pit and BDH Activated Carbons. Journal of Hazardous Materials, 158, 300-307. http://dx.doi.org/10.1016/j.jhazmat.2008.01.080 
[36] Cayllahua, J.E.B. and Torem, M.L. (2010) Biosorption of Aluminum Ions onto Rhodococcus opacus from Wastewaters. Chemical Engineering Journal, 161, 1-8. http://dx.doi.org/10.1016/j.cej.2010.03.025

[37] Khalil, M.M.H., Al-Wakeel, K.Z., Abd El Rehim, S.S. and Abd El Monem, H. (2013) Efficient Removal of Ferric Ions from Aqueous Medium by Amine Modified Chitosan Resins. Journal of Environmental Chemical Engineering, 1, 566-573. http://dx.doi.org/10.1016/j.jece.2013.06.022

[38] Akhtar, M., Iqbal, S., Kausar, A., Bhanger, M.I. and Shaheen, M.A. (2010) An Economically Viable Method for the Removal of Selected Divalent Metal Ions from Aqueous Solutions Using Activated Rice Husk. Colloids and Surfaces B: Biointerfaces, 75, 149-155. http://dx.doi.org/10.1016/j.colsurfb.2009.08.025

[39] Hassan, A.F., Mortada, W.I. and Hassanien, M.M. (2013) Preparation and Characterization of Activated Carbon Based Rice Husk and Its Use for Preconcentration of Pt (II). International Journal of Modern Chemistry, 5, 101-117.

[40] Daffalla, S.B., Mukhtar, H. and Shaharun, M.S. (2010) Characterization of Adsorbent Developed from Rice Husk: Effect of Surface Functional Group on Phenol Adsorption. Journal of Applied Sciences, 10, 1060-1067. http://dx.doi.org/10.3923/jas.2010.1060.1067

[41] Zhang, X., Su, H., Tan, T. and Xiao, G. (2011) Study of Thermodynamics and Dynamics of Removing Cu(II) by Biosorption Membrane of Penicillium Biomass. Journal of Hazardous Materials, 193, 1-9. http://dx.doi.org/10.1016/j.jhazmat.2011.03.014 
Scientific Research Publishing (SCIRP) is one of the largest Open Access journal publishers. It is currently publishing more than 200 open access, online, peer-reviewed journals covering a wide range of academic disciplines. SCIRP serves the worldwide academic communities and contributes to the progress and application of science with its publication.

Other selected journals from SCIRP are listed as below. Submit your manuscript to us via either submit@scirp.org or Online Submission Portal.
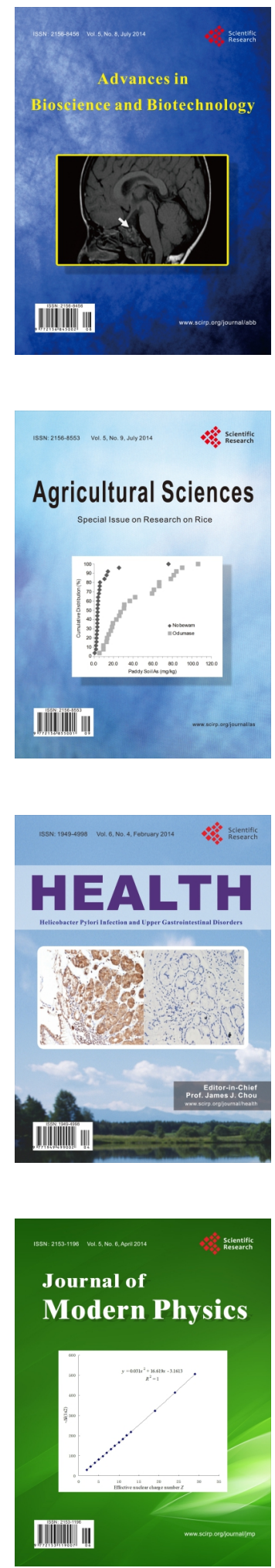
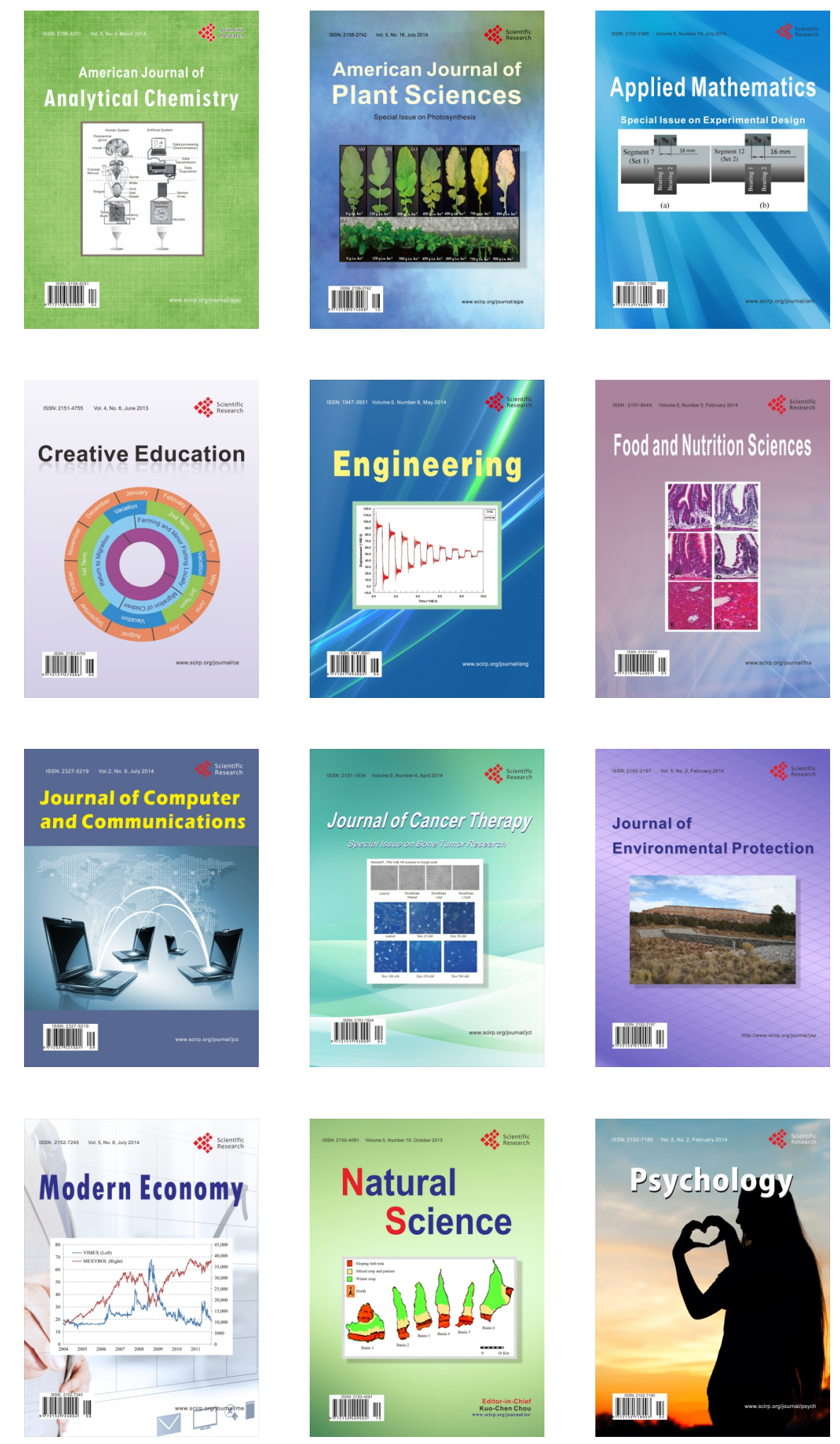